\title{
OCENA WPLYWU PROGRAMU ,RODZINA 500+” NA POLSKĄ GOSPODARKĘ ZA POMOCĄ MODELU CGE
}

\section{WPROWADZENIE}

Celem przedstawionego badania jest analiza wpływu programu „Rodzina 500+" na polska gospodarkę za pomocą obliczeniowego modelu równowagi ogólnej (ang. CGE - Computable General Equilibrium). Program wsparcia finansowego dla rodzin z dziećmi w Polsce, znany pod nazwa „Rodzina 500+”, jest częścią polityki demograficznej państwa. Program ten zakłada realizację trzech podstawowych celów:

- wzrost liczby urodzeń,

- ograniczenie ubóstwa, w szczególności wśród dzieci,

- inwestycja w rodzinę.

Program „Rodzina 500+” został wdrożony 1 kwietnia 2016 r. i początkowo dotyczył rodzin posiadających więcej niż jedno dziecko. Świadczenie w wysokości 500 zł miesięcznie przysługiwało na drugie i każde kolejne dziecko w wieku poniżej 18 lat. W lutym 2018 r. program został rozszerzony i objął także pierwsze dziecko (jedyne lub najstarsze dziecko w rodzinie), ale obowiązywało kryterium dochodowe, które wynosiło 800 zł netto miesięcznie na osobę w rodzinie lub $1200 \mathrm{zł}$ netto na osobę w rodzinie $\mathrm{z}$ niepełnosprawnym dzieckiem ${ }^{1}$. W lipcu 2019 r. kryterium dochodowe zostało zniesione i program już obejmuje wszystkie rodziny posiadajace dzieci w Polsce.

W 2016 r. na realizację celów programu „Rodzina 500+” przeznaczono 17,40 mld zł, w $2017-23,50$ mld zł, w $2018-22,17$ mld zł². Kwoty te stanowiły około 5\%-6\% łącznych wydatków budżetu państwa i około 1\%-1,2\% $\mathrm{PKB}^{3}$. Po zniesieniu kryterium dochodowego w lipcu 2019 r. znaczaco wzrosła liczba rodzin uprawnionych do otrzymywania świadczenia, dlatego w roku 2019 na program przeznaczono 31,77 mld zł, z kolei w roku 2020 - 40,2 mld zł. Liczba beneficjentów tego programu społecznego została podana w tabeli 1.

\footnotetext{
${ }^{1}$ Źródło: Ministerstwo Rodziny Pracy i Polityki Społecznej, Sprawozdanie Rady Ministrów z realizacji ustawy o pomocy państwa w wychowywaniu dzieci w latach 2016-2017, Warszawa 2018.

2 Źródło: Ministerstwo Rodziny, Pracy i Polityki Społecznej.

${ }^{3}$ Obliczenia własne na podstawie danych publikowanych przez GUS oraz Ministerstwo Finansów.
} 


\section{Tabela 1}

Średnia liczba rodzin i dzieci

\begin{tabular}{|l|c|c|}
\hline \multicolumn{1}{|c|}{ Rok } & Średnia liczba rodzin $(\mathbf{m l n})$ & Średnia liczba dzieci $(\mathbf{m l n})$ \\
\hline 2016 & 2,523 & 3,808 \\
\hline 2017 & 2,521 & 3,797 \\
\hline 2018 & 2,379 & 3,585 \\
\hline 2019 & 4,730 & $3,62-6,8$ \\
\hline 2020 & - & 6,8 \\
\hline
\end{tabular}

Źródło: Ministerstwo Rodziny, Pracy i Polityki Społecznej.

\section{Wykres 1}

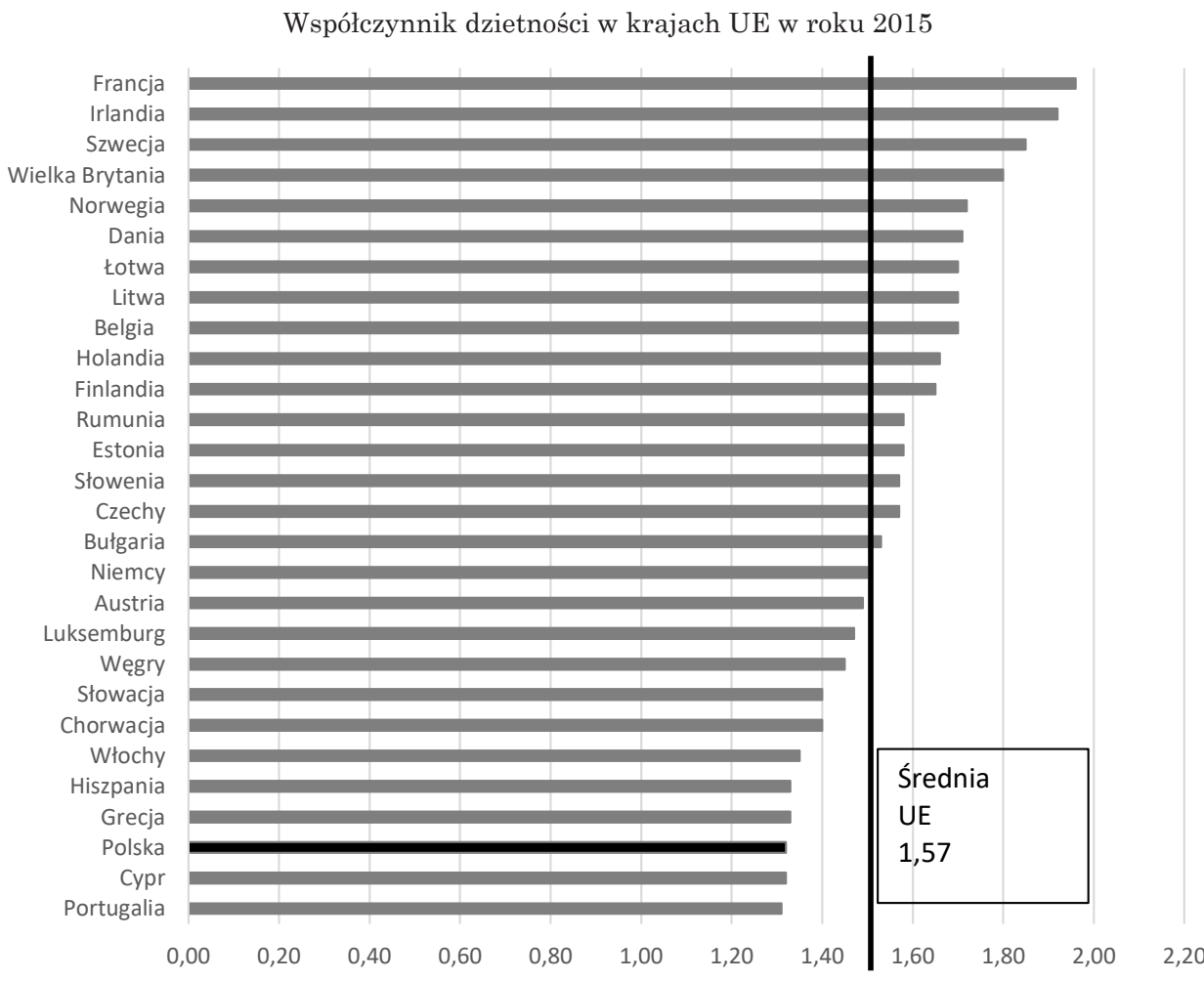

Źródło: dane Eurostatu.

W 2015 r. współczynnik dzietności w Polsce wynosił 1,294․ Jest to wartość poniżej progu tzw. prostej zastępowalności pokoleń ustalanej na poziomie ok. 2,1. (Dla porównania, w roku 1980 współczynnik dzietności w Polsce wyno-

${ }^{4}$ Współczynnik dzietności oznacza liczbę dzieci, którą urodziłaby przeciętnie kobieta w ciagu całego okresu rozrodczego (15-49 lat), przy założeniu, że w poszczególnych fazach tego okresu rodziłaby z intensywnością obserwowaną w badanym roku. Źródło definicji: GUS (2019): 178. 
sił 2,28, a w $1990-1,99^{5}$ ). Problem starzejącego się społeczeństwa dotyka nie tylko Polskę. Wykres 1 przedstawia współczynnik dzietności w Polsce na tle wszystkich krajów Unii Europejskiej i średniej dla UE w roku 2015.

Pomoc finansowa dla rodzin z dziećmi jest dostępna również w innych krajach UE. Osiemnaście spośród 28 krajów UE (skład UE w 2015) oferuje świadczenia niezależne od dochodu. W tabeli 2 przedstawiono uśrednione miesięczne wsparcie finansowe dla rodzin posiadajacych dzieci w tych krajach. W pozostałych krajach UE (Bułgaria, Cypr, Chorwacja, Czechy, Hiszpania, Grecja, Włochy, Portugalia i Słowenia) świadczenia są uzależnione od dochodu, przy czym najniższe są w Bułgarii i Grecji (10-18 EUR), a najwyższe - we Włoszech i Słowenii (ok. 140 EUR).

Tabela 2

Miesięczne wsparcie finansowe dla rodzin bez kryterium dochodowego (EUR)

\begin{tabular}{|c|c|c|c|c|c|c|c|}
\hline Kraj & $\stackrel{1}{\text { dziecko }}$ & $\begin{array}{c}2 \\
\text { dzieci }\end{array}$ & $\begin{array}{c}3 \\
\text { dzieci }\end{array}$ & $\begin{array}{c}4 \\
\text { dzieci }\end{array}$ & $\begin{array}{c}\mathbf{5} \\
\text { dzieci }\end{array}$ & $\begin{array}{c}6 \\
\text { dzieci }\end{array}$ & $\begin{array}{c}7 \\
\text { dzieci }\end{array}$ \\
\hline Austria & 134 & 141 & 151 & 160 & 165 & 169 & 184 \\
\hline Belgia & 90 & 167 & 249 & 249 & 249 & 249 & 249 \\
\hline Dania & 126 & 126 & 126 & 126 & 126 & 126 & 126 \\
\hline Estonia & 45 & 45 & 100 & 100 & 100 & 100 & 100 \\
\hline Finlandia & 96 & 106 & 135 & 155 & 174 & 174 & 174 \\
\hline Francja & 0 & 129 & 166 & 295 & 166 & 166 & 166 \\
\hline Holandia & 79 & 79 & 79 & 79 & 79 & 79 & 79 \\
\hline Irlandia & 135 & 135 & 135 & 135 & 135 & 135 & 135 \\
\hline Luksemburg & 186 & 255 & 362 & 362 & 362 & 362 & 362 \\
\hline Łotwa & 11 & 23 & 34 & 34 & 34 & 34 & 34 \\
\hline Malta & 96 & 96 & 96 & 96 & 96 & 96 & 96 \\
\hline Niemcy & 188 & 188 & 194 & 219 & 219 & 219 & 219 \\
\hline Rumunia & 87 & 87 & 87 & 87 & 87 & 87 & 87 \\
\hline Słowacja & 24 & 24 & 24 & 24 & 24 & 24 & 24 \\
\hline Szwajcaria & 166 & 166 & 166 & 166 & 166 & 166 & 166 \\
\hline Szwecja & 114 & 130 & 178 & 284 & 416 & 580 & 580 \\
\hline Węgry & 38 & 42 & 51 & 51 & 51 & 51 & 51 \\
\hline $\begin{array}{l}\text { Wielka } \\
\text { Brytania }\end{array}$ & 97 & 64 & 64 & 64 & 64 & 64 & 64 \\
\hline
\end{tabular}

Źródło: Ministerstwo Rodziny, Pracy i Polityki Społecznej, <https://www.gov.pl/web/rodzina/zestawienie-swiadczen-na-dzieci-w-ueeog1> [dostęp: 17.11.2019].

\footnotetext{
${ }^{5}$ Źródło: GUS (2016): 287.
} 
Celem zaprezentowanego w niniejszym artykule badania jest odpowiedź na pytanie, w jaki sposób wprowadzenie tego programu socjalnego wpłynie na polska gospodarkę oraz jaka jest skala wpływu na główne zmienne makroekonomiczne - produkcję, konsumpcję, import, eksport i inwestycje. Główna hipoteza badawcza brzmi następująco: wpływ programu „Rodzina 500+” na główne zmienne makroekonomiczne zależy od wyboru źródła finansowania progra$\mathrm{mu}$ - zwiększenie deficytu budżetowego lub wzrost obciążeń podatkowych.

Na potrzeby badania został stworzony model z klasy CGE. Modele CGE są narzędziami analitycznymi często używanymi do wspomagania decyzji jednostek rządowych dotyczących implementacji różnych rozwiązań legislacyjnych - na przykład do oceny skutków zmian wysokości podatków, zmian polityki handlowej kraju, a także zmian polityki środowiskowej. Procedura badawcza polega na skonstruowaniu modelu CGE, jego kalibracji, a następnie zdefiniowaniu zasad domknięcia modelu. Skalibrowany model odzwierciedla stan gospodarki w danym roku i umożliwia testowanie alternatywnych scenariuszy zgodnie z założeniami analizowanej polityki.

W kolejnych częściach artykułu przedstawiono publikacje związane z programem „Rodzina 500+”, metodę badawczą założenia modelu i przyjęte scenariusze. Następnie przedstawiono wyniki symulacji, a także dokonano analizy wyników post factum. Na zakończenie przedstawiono główne wnioski z badania.

\section{BADANIA DOTYCZĄCE PROGRAMU „RODZINA 500+”}

Od momentu jego wprowadzenia program „Rodzina 500+” ma zarówno wielu zwolenników, jak i przeciwników, jest również obiektem wielu komentarzy, dyskusji politycznych, a także analiz i badań naukowych. Część badań skupia się na aspektach demograficznych i ocenie osiagnięcia jego deklarowanych celów w stosunku do kosztów, inne skupiają się na wpływie tej polityki na rozkład dochodów gospodarstw domowych, a także na konsekwencjach dla rynku pracy.

Michał Myck ${ }^{6}$ używa modelu podaży pracy z dyskretnym wyborem, aby oszacować implikacje dla podaży pracy związane z programem „Rodzina 500+”, i stwierdza, że program znacząco zmienił równowagę zachęt finansowych do pracy wśród rodziców. Jego szacunki sugeruja, że podaż pracy wśród rodzin z dziećmi się zmniejszy o około 240000 osób, głównie matek w rodzinach z jednym lub dwojgiem dzieci, i że efekty podaży siły roboczej będą odczuwane najsilniej w małych miasteczkach i wsiach.

Stanisława Golinowska i Agnieszka Sowa-Kofta ${ }^{7}$ analizuja wyniki programu z punktu widzenia deklarowanych celów politycznych świadczenia pieniężnego, szczególnie radykalnego ograniczenia ubóstwa dzieci i poprawy dzietności. Ich wstępne wyniki pokazuja, że udało się zmniejszyć ubóstwo do-

\footnotetext{
${ }^{6}$ Myck (2016): 1-18.

${ }^{7}$ Golinowska, Sowa-Kofta (2017): 7-13.
} 
chodowe w wielu rodzinach, poprawiając strukturę konsumpcji na potrzeby całej rodziny, ale jednocześnie zwiększając tendencję matek do opuszczania rynku pracy. Zaznaczono jednak, że zjawisko to rozpoczęło się w Polsce jeszcze przed wdrożeniem świadczenia „500+”. Maria Pierzchalska ${ }^{8}$ z kolei zwraca uwagę na inne bariery uczestnictwa kobiet w rynku pracy, takie jak brak elastyczności czasu pracy, nierówności w zarobkach, niezdolność do pogodzenia pracy z obowiązkami rodzinnymi oraz lęk przed biernością zawodowa. Piotr Szukalski ${ }^{9}$ dochodzi do wniosku, że w latach 2016 i 2017 zaobserwowano wyraźny wzrost liczby urodzeń i współczynnika dzietności oraz stwierdza wzrost urodzeń pierwszych, a jednocześnie zmianę zachowań prokreacyjnych w zakresie urodzeń drugich i trzecich, polegająca na przyspieszeniu momentu decyzji o posiadaniu kolejnych dzieci. Krzysztof Hagemejer ${ }^{10}$ pokazuje, że całkowite wydatki na ochronę socjalna, a także wydatki na świadczenia rodzinne w Polsce - mierzone jako procent PKB - są znacznie niższe niż średnia UE. Wydatki na świadczenia pieniężne w 2012 r. wyniosły 0,7\% PKB, znacznie mniej niż średnia UE wynosząca 1,6\%. Wprowadzenie programu „Rodzina 500+” ponad dwukrotnie zwiększyło stosunek wydatków do PKB, dzięki czemu w 2016 r. wyniosły one 1,85\% PKB i można wnioskować, że w 2017 wydatki na wszystkie rodzaje rodzinnych świadczeń pieniężnych przekroczą $2 \%$.

Michał Brzeziński i Mateusz Najsztub ${ }^{11}$ z kolei wykorzystują podejście mikrosymulacyjne i dane z badania budżetu domowego z 2015 r., aby oszacować krótkoterminowy wpływ programu „Rodzina 500+” na dochody gospodarstw domowych, ubóstwo i nierówności. Ich wyniki sugeruja, że program będzie miał największy wpływ na dochody gospodarstw domowych w dolnej części rozkładu dochodów. Artykuł pokazuje również, że program zmniejszy wskaźnik nierówności dochodów Giniego w Polsce o kilka punktów procentowych. Program może prowadzić do niższego ryzyka skrajnego ubóstwa w gospodarstwach domowych z dziećmi w porównaniu z małymi gospodarstwami domowymi (np. jednoosobowymi). Postępujący wpływ programu „Rodzina 500+” na rozkład dochodów w Polsce może zostać w dłuższej perspektywie zmniejszony, jeżeli negatywnie wpłynie to na aktywność gospodarstw domowych o niskich dochodach na rynku pracy.

Paulina Radzik ${ }^{12}$ również omawia wpływ rządowego programu „Rodzina 500+” na rynek pracy. Głównym celem programu jest pomoc rodzinom w kosztach wychowania dzieci, co w dłuższej perspektywie może poprawić sytuację demograficzna w Polsce. Z drugiej strony to rozwiąanie może zachęcić wiele kobiet do rozwiązania umów o pracę lub pozostawania bez pracy. Mariola Chrzanowska, Joanna Landmesser i Hanna Dudek ${ }^{13}$ pokazuja, w jaki sposób zmieni się sytuacja finansowa polskich gospodarstw po wprowadzeniu programu „Rodzina 500+”. Rozważano takie efekty redystrybucyjne reformy,

\footnotetext{
8 Pierzchalska (2017): 42-50.

9 Szukalski (2018): 1-4.

${ }^{10}$ Hagemejer (2017): 1-7.

11 Brzeziński, Najsztub (2017): 16-25.

12 Radzik (2017): 57-65.

${ }^{13}$ Chrzanowska, Landmesser (2017): 38-46; Landmesser, Dudek, Chrzanowska (2017): 50-512.
} 
jak jej wpływ na zakres i głębokość ubóstwa oraz na nierówności dochodowe (wykorzystywano przy tym dane z BBGD). W pierwszym z artykułów przeprowadzono również rozważania na temat alternatywnego kształtu reformy (polskie rozwiązania zastapiono elementami o odmiennej konstrukcji z zagranicznych systemów wsparcia rodzin, a ich hipotetyczne efekty porównano). Drugi artykuł zawiera wyniki symulacji skutków programu „Rodzina 500+” przeprowadzonych za pomoca modelu EUROMOD (ang. European tax-benefit microsimulation model).

Z kolei Agnieszka Wiśniewska, Marta Musiał i Beata Świecka ${ }^{14}$ wskazuja, że efekty programu „Rodzina 500+” są zarówno pozytywne, jak i negatywne. Niektóre efekty programu są już widoczne, chociaż wiele prognoz nie zostało jeszcze potwierdzonych $\mathrm{w}$ statystykach ze względu na krótki czas trwania programu. Anna Ruzik-Sierdzińska ${ }^{15}$ omawia dotychczasowy wpływ programu „Rodzina 500+” na trzy obszary: liczbę urodzeń, ubóstwo w rodzinach z dziećmi i aktywność zawodową rodziców (zwłaszcza matek) małych dzieci. Wyniki jej analizy wskazuja, że nowe świadczenie obniżyło poziom ubóstwa wśród rodzin z dziećmi, zwiększyło liczbę urodzeń - choć może to być efekt przejściowy i związany także z innych zmianami wprowadzanymi w latach 2013-2016 a także zmniejszyło aktywność zawodowa, głównie kobiet. Iga Magda, Aneta Kiełczewska i Nicola Brandt ${ }^{16}$ również stwierdzaja, że program może zmniejszyć zachęty do uczestnictwa w rynku pracy. Szacunki wskazuja, że do połowy 2017 r. wskaźnik aktywności zawodowej matek spadł o 2-3 punkty procentowe w wyniku świadczenia „Rodzina 500+”. Efekt był większy wśród kobiet o niższym poziomie wykształcenia i mieszkających w małych miejscowościach.

Wyczerpujący i szczegółowy przegląd literatury związanej z programem „Rodzina 500+” przedstawia Aneta Kłopocka ${ }^{17}$. Z kolei Biuro Analiz Sejmowych Kancelarii Sejmu ${ }^{18}$ zwraca uwagę, że wprowadzenie proponowanych regulacji dotyczących rozszerzenia programu bez kryterium dochodowego wiązać się będzie ze znacznym obciążeniem budżetu państwa. Może być ono uznawane za nieadekwatne wobec oczekiwanych rezultatów. Rezygnacja z kryterium dochodowego, wbrew założeniom projektodawców dotyczącym wyrównywania szans, może skutkować transferami środków nie do najbiedniejszych, ale do rodzin o średnich i wyższych dochodach. W innym raporcie, opracowanym przez zespół SGH „Rodzina 500+ - ocena programu i propozycje zmian”, zwraca się uwagę, że: „Według GUS zmniejszenie ubóstwa rodzin z dziećmi następuje w znacznie mniejszej skali niż zakładano to przy wprowadzaniu programu. Zaledwie 37 proc. pieniędzy wydawanych w ramach programu trafia do rodzin ubogich, a tylko nieco ponad 12 proc. środków przeznaczanych przez państwo na »500+« wystarczyłoby na zniwelowanie skrajnego ubóstwa dzieci.

14 Wiśniewska, Musiał i Święcka (2017): 490-494.

15 Ruzik-Sierdzińska (2018): 63-76.

16 Magda, Kiełczewska i Brandt (2018).

17 Kłopocka (2019): 73-83.

18 Biuro Analiz Sejmowych Kancelarii Sejmu, Ocena skutków regulacji zawartych w rządowym projekcie ustawy o zmianie ustawy o pomocy państwa w wychowywaniu dzieci oraz niektórych innych ustaw, 2019 (nr druku 3387). 
Natomiast obecnie ok. 1,5 mld złotych z programu trafia do rodzin najbogatszych, a dzięki rozszerzeniu »500+« także na każde pierwsze dziecko trafi do nich kolejnych 5 mld złotych"19.

Na podstawie przytoczonych publikacji nie można sformułować jednoznacznych wniosków. Z jednej strony program „Rodzina 500+” zwiększył dochody gospodarstw domowych, obniżył poziom ubóstwa wśród rodzin z dziećmi, zwiększył liczbę urodzeń, choć być może efekty te są przejściowe. Z drugiej przyczynił się do zmian na rynku pracy, a także zwiększył obciążenie budżetu. Niektórzy autorzy wskazuja, że koszt jest zbyt wysoki.

Niniejsza analiza nie ma na celu oceny skuteczności czy słuszności programu „Rodzina 500+”, stanowi jedynie próbę odpowiedzi na pytanie, jakie będą konsekwencje wprowadzenia tej polityki dla polskiej gospodarki, za pomoca obliczeniowego modelu równowagi ogólnej CGE (ang. Computable General Equilibrium)

\section{METODA BADAWCZA}

Modele z klasy CGE konstruowane są w konkretnych celach i służą przede wszystkim do różnego rodzaju analiz scenariuszowych. Modele te sa wykorzystywane także jako narzędzie badania skutków wprowadzenia różnych programów socjalnych na dobrobyt kraju. Hong Jung i Erik Thorbecke ${ }^{20}$ na przykład badają wpływ zwiększenia wydatków na cele edukacyjne na kapitał ludzki. Ernest Odior ${ }^{21}$ oraz Hakeem Eltalla ${ }^{22}$ z kolei analizują wpływ wydatków rządowych na wzrost gospodarczy.

W odróżnieniu od modeli ekonometrycznych, w których zakłada się, że badany segment rzeczywistości jest odizolowany od reszty gospodarki, w modelach CGE gospodarka rozpatrywana jest jako całość, w której rynki sa ze soba powiązane przez mechanizm podaży i popytu. Wartości parametrów modelu nie sa szacowane, lecz sa obliczane na podstawie danych makroekonomicznych - jest to tzw. kalibracja modelu. Modele te bazują na ogólnej teorii równowagi, która łączy założenia behawioralne racjonalnych podmiotów ekonomicznych z analizą warunków równowagi. Zachowania producentów opisywane sa za pomocą funkcji produkcji, a konsumentów - za pomoca funkcji użyteczności. Podstawowym założeniem modeli z klasy CGE jest równowaga rynków dla wszystkich czynników produkcji i dóbr. Szczególną rolę w tym modelowaniu odgrywa opis relacji między zmiennymi. Modele CGE wykorzystuja dużą liczbę zmiennych. Struktura gospodarki jest ujęta w blokach opisujących poszczególne elementy w gospodarce - np. bloki produkcji, czynników produk-

19 Raport: Rodzina 500 plus - ocena programu i propozycja zmian, <https://for.org.pl/pl/publikacje/raporty-for/raport-rodzina-500-plus-ocena-programu-i-propozycje-zmian>.

20 Jung, Thorbecke (2003): 701-725.

21 Odior (2011): 74-87.

22 Eltalla (2017): 2222-2855. 
cji, gospodarstw domowych, administracji rządowej, handlu zagranicznego, blok kapitałowy (inwestycje-oszczędności) itd.

Model wykorzystany w niniejszej analizie należy do klasy modeli równowagi ogólnej, wywodzących się z podejścia do modelowania CGE opisanego przez Kemala Dervisa, Jaimego de Melo i Shermana Robinsona ${ }^{23}$, a następnie rozwiniętych przez Shermana Robinsona, Maureen Kilkenny i Kenneta Hansona ${ }^{24}$ oraz Shantayanana Devarajana, Jeffreya Lewisa i S. Robinsona ${ }^{25}$. Dokumentację techniczną modelu można znaleźć w pracy Scotta McDonalda i Karen Thierfelder ${ }^{26}$. Jest to statyczny model równowagi ogólnej jednego kraju (ang. single country static CGE model). Zmienne podzielone sa w następujących blokach: Czynniki produkcji, Firmy, Gospodarstwa domowe, Dobra, Rząd, Blok kapitałowy (oszczędności-inwestycje) oraz Resztę świata. Uproszczoną strukturę gospodarki, a także okrężny ruch pieniądza pokazano na schemacie 1 .

\section{Schemat 1}

Struktura gospodarki w modelu

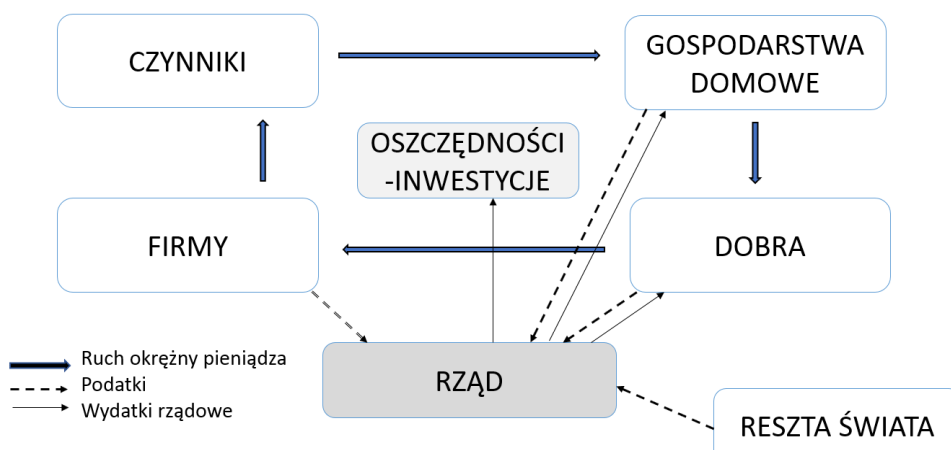

Źródło: opracowanie własne.

Firmy w celu realizacji swoich planów produkcyjnych kupują czynniki produkcji, które sa własnościa gospodarstw domowych, a te zgłaszaja popyt na dobra produkowane przez firmy. W modelu uwzględniony jest także rząd, który pobiera podatki w celu realizacji swojej polityki przez wydatki rządowe. Kraj jest powiązany z reszta świata przez import i eksport. Zachowania producentów modelowane są za pomocą funkcji produkcji Cobba-Douglasa, a gospodarstw domowych - za pomoca funkcji użyteczności takiej samej postaci analitycznej jak funkcja produkcji Cobba-Douglasa. Model uwzględnia także zużycie pośrednie, które jest opisane za pomocą współczynników Leontiefa.

\footnotetext{
${ }^{23}$ Dervis, de Melo, Robinson (1982).

${ }^{24}$ Robinson, Kilkenny, Hanson (1990).

25 Devarajan, Lewis, Robinson (1994).

${ }_{26}$ McDonald, Thierfelder (2007).
} 
Zapis modelu CGE, wykorzystanego w prezentowanym badaniu, zawiera ponad 120 równań oraz zmiennych ${ }^{27}$. Z uwagi na dużą liczbę zmiennych kalibracja modeli tego typu wymaga użycia specjalistycznego oprogramowania. Model ten został skalibrowany za pomoca programu GAMS (ang. General Algebraic Modeling System ${ }^{28}$, składającego się z kompilatora języka i zintegrowanych wysoko wydajnych solverów. GAMS jest oprogramowaniem przeznaczonym do rozwiązywania zadań programowania matematycznego i optymalizacji, dostosowanym do złożonych aplikacji i modelowania na dużą skalę. Program ten pozwala budować i rozwiązywać duże modele, które można szybko dostosować do nowych sytuacji.

Po zdefiniowaniu bloków, zmiennych i równań w modelu CGE kolejnym etapem jest jego kalibracja. Kalibracja jest procedura matematyczną i polega na obliczeniu parametrów modelu na podstawie danych opisujących stan gospodarki w danym roku. Modele CGE sa kalibrowane na podstawie danych, przedstawionych w postaci tablicy SAM (ang. Social Accounting Matrix). Jest to zbilansowana, kwadratowa macierz reprezentujacca rachunki gospodarcze i społeczne danego kraju, która służy do identyfikacji stanu początkowego gospodarki. Tablica SAM pełni także ważną rolę organizacyjną dla grup agentów w gospodarce. Źródłem danych do konstrukcji tablicy SAM sa przede wszystkim tablice przepływów międzygałęziowych, dostępne na stronie Eurostatu lub w bazach danych WIOD, EORA czy GTAP. Podejście do konstruowania tablicy SAM pochodzi od Grahama Pyatta ${ }^{29}$.

Do konstrukcji tablicy SAM dla Polski wykorzystano dane z tablicy przepływów międzygałęziowych dla Polski dla roku 2015, opublikowanej na stronie GUS, a także informacje o deficycie budżetowym ze strony Ministerstwa Finansów za rok 2015. Jest to rok bazowy, gdyż program „Rodzina 500+” został wprowadzony w tym właśnie roku.

\section{ZALOŻENIA MODELU I PRZYJĘTE SCENARIUSZE}

W każdym modelu CGE należy określić zasady domknięcia modelu. Ogólnie zasady domknięcia dotyczą podziału zmiennych na endogeniczne i egzogeniczne. Na przykład zasady domknięcia bloku rządowego określaja, w jaki sposób będą finansowane zwiększone wydatki rządowe. Zasady domknięcia bloku kapitałowego (oszczędności-inwestycje) z kolei określaja, czy w gospodarce inwestycje sa determinowane przez oszczędności czy odwrotnie. Ostatnim etapem jest zdefiniowanie scenariuszy (tzw. szoków) i zbadanie reakcji układu gospodarczego na nie.

${ }^{27} \mathrm{~W}$ zależności od poziomu dezagregacji ta liczba może być o wiele większa.

28 Konkurencyjnym pakietem oprogramowania do modelowania ekonomicznego, także odpowiednim do kalibracji modeli równowagi ogólnej, jest GEMPACK.

${ }^{29}$ Pyatt (1987): 327-352; (1991): 315-341. 
Po kalibracji modelu dla Polski dla roku 2015 wybrano dwa sposoby domknięcia bloku rządowego. Z uwagi na fakt, że realizacja programu „Rodzina 500+” może być finansowana z różnych źródeł, należy rozważyć następujące możliwości:

- wzrost deficytu budżetowego,

- wzrost przychodów (np. przychodów podatkowych),

- zmniejszenie innych wydatków.

Trzecia możliwość wydaje się mało prawdopodobna, dlatego w bloku „Rząd” wybrano jako zasady domknięcia modelu dwie pierwsze możliwości - za pomocą deficytu budżetowego, nazywane dalej „Domknięciem I”, oraz za pomoca wzrostu przychodów (obciążeń podatkowych), zwane dalej „Domknięciem II”.

Różnicą między dochodami rządowymi (IG) a wydatkami rządowymi (EG) jest deficyt (lub nadwyżka) budżetu Państwa (GOV):

$$
\mathrm{GOV}=\mathrm{IG}-\mathrm{EG} \text {. }
$$

Po wprowadzeniu programu wydatki rządowe (EG) wzrosna, stąd możliwe jest ich finansowanie za pomoca wzrostu zmiennej (GOV) lub wzrostu zmiennej (IG). Innymi słowy, pierwsze domknięcie zakłada, że program będzie finansowany za pomocą zwiększenia deficytu budżetowego, a drugie - za pomocą wzrostu dochodów (podatków).

Następnym etapem jest określenie możliwych scenariuszy.

Scenariusze, jakie wzięto pod uwagę, to wzrost transferów socjalnych o:

$-10 \mathrm{mld}$,

$-20 \mathrm{mld}$,

-40 mld.

Scenariusze te oznaczono dalej jako sim01, sim02 i sim03, a punkt wyjścia (poziom bazowy) jako base.

W tabeli 3 podano wartości zmiennych GOV oraz IG dla trzech scenariuszy. Za poziom bazowy przyjęto deficyt budżetowy w roku 2015, który wynosił 42,607 mld zł. Domknięcie I zakłada wzrost deficytu budżetowego przy niezmienionym poziomie dochodów budżetowych. Domknięcie II zakłada wzrost przychodów budżetowych przy niezmienionym poziomie deficytu budżetowego.

Tabela 3

Zmiany deficytu budżetowego (GOV) oraz dochodów budżetu (IG) (mld zł)

\begin{tabular}{|c|c|c|c|c|}
\hline Domknięcie / Scenariusz & base & $\operatorname{sim} 01$ & $\operatorname{sim} 02$ & $\operatorname{sim} 03$ \\
\hline Wzrost wydatków (EG) & 0 & +10 & +20 & +40 \\
\hline Domknięcie I (GOV) & $-42,607$ & $-52,607$ & $-62,607$ & $-82,607$ \\
\hline Domknięcie I (IG) & bez zmian & bez zmian & bez zmian & bez zmian \\
\hline Domknięcie II (GOV) & $-42,607$ & $-42,607$ & $-42,607$ & $-42,607$ \\
\hline Domknięcie II (IG) & 0 & +10 & +20 & +40 \\
\hline
\end{tabular}

Źródło: opracowanie własne. 
Przy domknięciu II, zakładającym wzrost obciążeń podatkowych, należy również określić, która pozycja przychodów budżetu wzrośnie. Strukturę przychodów budżetowych w 2015 r. podano w tabeli 4. Z uwagi na fakt, że największy jest udział przychodów z podatku VAT, domknięcie II zakłada wzrost przychodów z podatku VAT.

\section{Tabela 4}

Struktura przychodów budżetowych w Polsce w roku 2015

\begin{tabular}{|l|c|c|}
\hline \multicolumn{1}{|c|}{ Tytul przychodów } & Przychody (mld zł) & Udział \\
\hline CIT & 25,813 & $8,9 \%$ \\
\hline PIT & 45,040 & $15,6 \%$ \\
\hline VAT & 123,121 & $42,6 \%$ \\
\hline Inne podatki & 65,699 & $22,7 \%$ \\
\hline Dochody niepodatkowe & 27,710 & $9,6 \%$ \\
\hline UE & 1,753 & $0,6 \%$ \\
\hline Razem & $\mathbf{2 8 9 , 1 3 6}$ & $\mathbf{1 0 0} \%$ \\
\hline
\end{tabular}

Źródło: opracowane własne na podstawie danych Ministerstwa Finansów.

Blok kapitałowy (oszczędności-inwestycje) również może być domknięty za pomocą różnych reguł. Pierwsza z nich, znana jako domknięcie „neoklasyczne”, zakłada, że gospodarka jest napędzana oszczędnościami (ang. savings-driven), czyli poziom inwestycji dostosowuje się do poziomu oszczędności. Z kolei domknięcie keynesowskie zakłada, że gospodarka jest napędzana inwestycjami (ang. investment-driven), a zatem poziom oszczędności dostosowuje się do poziomu inwestycji. Blok ten jest bardzo ważny z punktu widzenia prezentowanej analizy, gdyż sposób jego domknięcia ma decydujacy wpływ na otrzymane później wyniki. Wybór domknięcia bloku kapitałowego jest kluczowa decyzją w każdym modelu CGE - wynika on z przekonania, jak funkcjonuje gospodarka: czy za pomoca kreacji pieniądza i wzrostu zadłużenia można zwiększyć dochód czy nie? Jak wiadomo, teoria ekonomii nie podaje jednoznacznej odpowiedzi na to pytanie. Wśród ekonomistów należących do dwóch głównych nurtów - neoklasycznego i keynesowskiego - nadal nie ma zgodności na ten temat. W związku z tym, że celem analizy nie jest rozstrzygnięcie tego trwającego od lat sporu, najpierw przyjęto neoklasyczne domknięcie bloku kapitałowego, a następnie w celu porównania - domknięcie keynesowskie. Jednak należy mieć na uwadze, że domknięcie neoklasyczne, zgodnie z teorią neoklasyczna, zakłada, że źródłem kapitału na inwestycje sa oszczędności, natomiast domknięcie keynesowskie zakłada, że popyt inwestycyjny może być zaspokajany za pomoca kreacji pieniądza. 


\section{WYNIKI SYMULACJI}

Wyniki symulacji dla trzech scenariuszy, oznaczonych jako sim01, sim02 i sim03, zostana przedstawione dla następujących zmiennych makroekonomicznych: produkcja krajowa, zużycie pośrednie, import, eksport, konsumpcja oraz inwestycje. W pierwszym podejściu dla bloku kapitałowego (inwestycje-oszczędności) przyjęto domknięcie neoklasyczne.

Wykres 2

Zmiany w produkcji krajowej i zużycia pośredniego

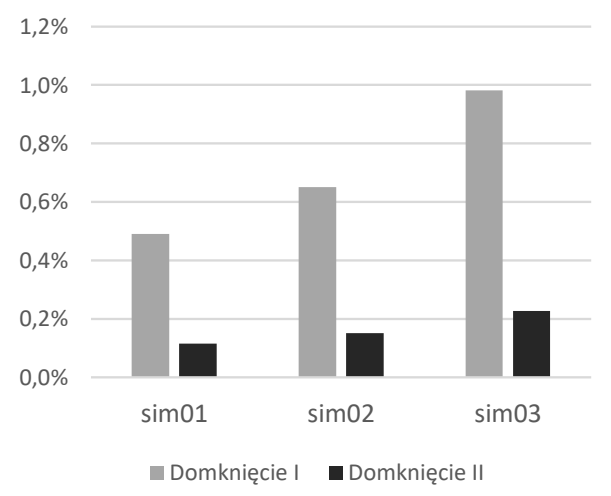

a) Produkcja krajowa

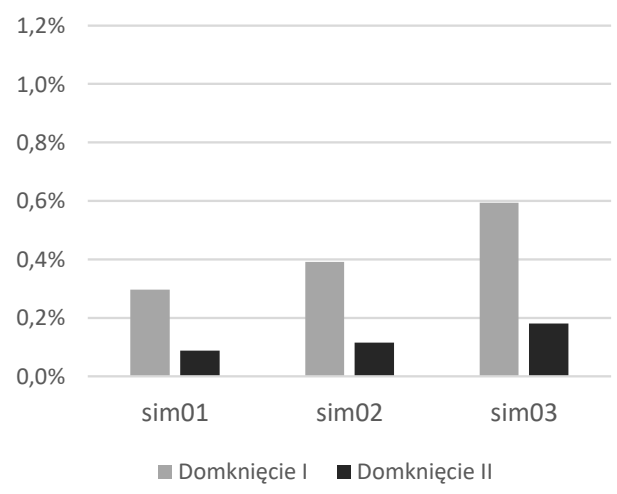

b) Zużycie pośrednie

Źródło: obliczenia własne na podstawie modelu CGE.

Na wykresie 2a przedstawiono zmiany produkcji krajowej dla trzech scenariuszy dla domknięcia I (deficyt budżetowy) oraz II (wzrost dochodów budżetowych), a wykres $2 \mathrm{~b}$ - analogicznie, zmiany zużycia pośredniego. Wzrost produkcji krajowej może osiagnać prawie $1 \%$ przy scenariuszu 3 , a odpowiadający jej wzrost zużycia pośredniego wynosi $0,6 \%$. Efekty są silniejsze w przypadku domknięcia I, ponieważ zakłada ono wzrost deficytu, a nie wzrost podatków. Jest to zgodne z keynesowskim podejściem stymulowania gospodarki za pomocą deficytu. Wzrost popytu jest większy, ale konsekwencją ekonomiczną takiej polityki jest zwiększenie zadłużenia kraju.

Z kolei na wykresie 3 przedstawiono zmiany importu i eksportu dla trzech scenariuszy. Zmiany w imporcie spowodowane sa wzrostem popytu konsumpcyjnego, natomiast zmiany eksportu są nieznaczne.

Ostatnia para zmiennych to konsumpcja i inwestycje. Na wykresie 4 pokazano ich zmiany dla trzech scenariuszy. Wzrost konsumpcji dla scenariusza 3 sięgnie $1,5 \%$, przy towarzyszącym spadku inwestycji około $4 \%$.

Wyniki wskazuja że przy obu sposobach domknięcia budżetu wzrost konsumpcji wiąże się ze spadkiem inwestycji. Wynika to z zasady domknięcia bloku kapitałowego - domknięcie neoklasyczne. Dla celów porównawczych poniżej przedstawiono wyniki dla zmiennych konsumpcja i inwestycje również dla keynesowskiego domknięcia bloku kapitałowego. 


\section{Wykres 3}
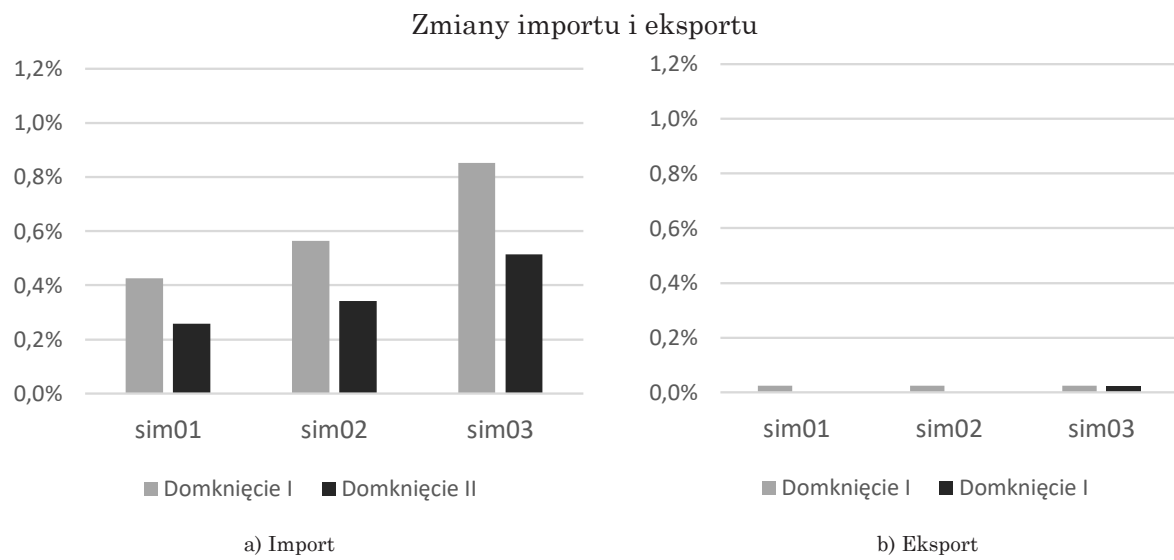

a) Import

b) Eksport

Źródło: obliczenia własne na podstawie modelu CGE.

\section{Wykres 4}

Zmiany konsumpcji i inwestycji

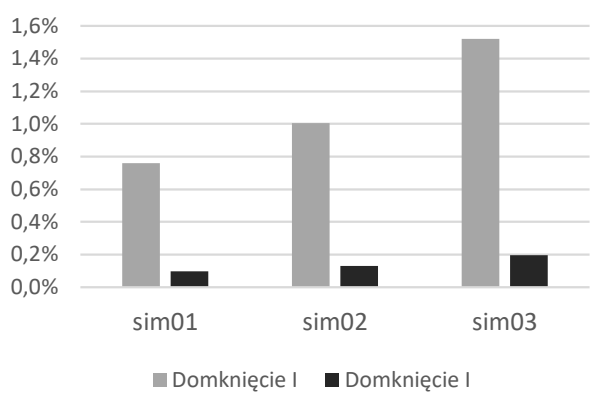

a) Konsumpcja

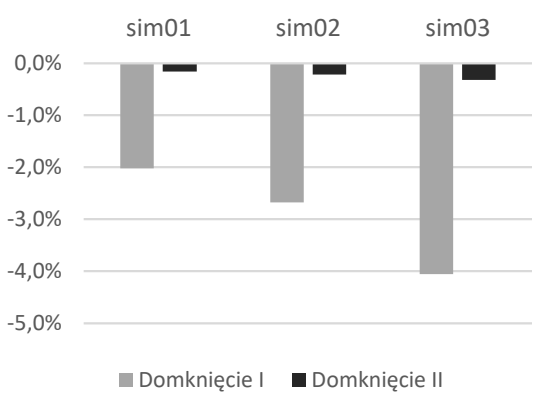

b) Inwestycje

Źródło: obliczenia własne na podstawie modelu CGE.

\section{Wykres 5}

Zmiany inwestycji - domknięcie neoklasyczne i domknięcie keynesowskie

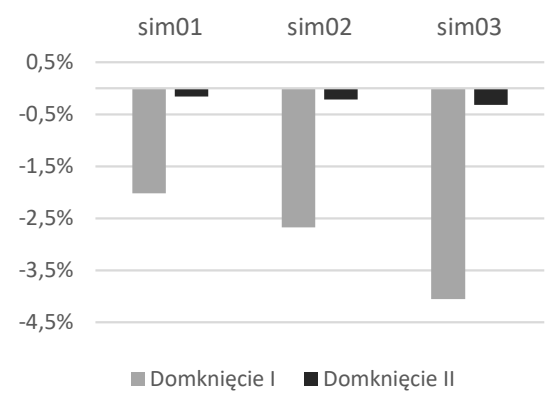

a) Domknięcie neoklasyczne

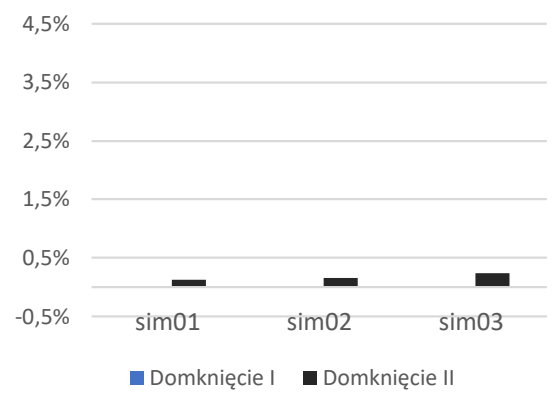

b) Domknięcie keynesowskie

Źródło: obliczenia własne na podstawie modelu CGE. 
Jeżeli porównamy zmiany w inwestycjach okazuje się, że reguła domknięcia bloku kapitałowego ma istotny wpływ na wyniki. Przy domknięciu neoklasycznym, czyli przy założeniu, że gospodarka napędzana jest oszczędnościami, wpływ na inwestycje będzie ujemny. Wpływ ten jest silniejszy, gdy program finansowany jest za pomocą wzrostu deficytu budżetowego. Przy keynesowskim domknięciu bloku kapitałowego, w przypadku finansowania programu deficytem wpływ na inwestycje jest znikomy, natomiast przy domknięciu II spodziewany jest niewielki wzrost inwestycji (ok. 0,3\% przy scenariuszu 3). Krótko mówiąc, zwiększony popyt konsumpcyjny przy keynesowskim domknięciu spowoduje wzrost inwestycji.

\section{ANALIZA POST FACTUM}

Od momentu wprowadzenia programu „Rodzina 500+” upłynęło ponad 3 lata, można się zatem pokusić o sprawdzenie zasadności wyborów reguł domknięcia modelu. Pierwszy wybór domknięcia dotyczył bloku rządowego, czyli sposobu finansowania programu.

Wykres 6

Budżet państwa w latach 2015-2018 (mld zł)

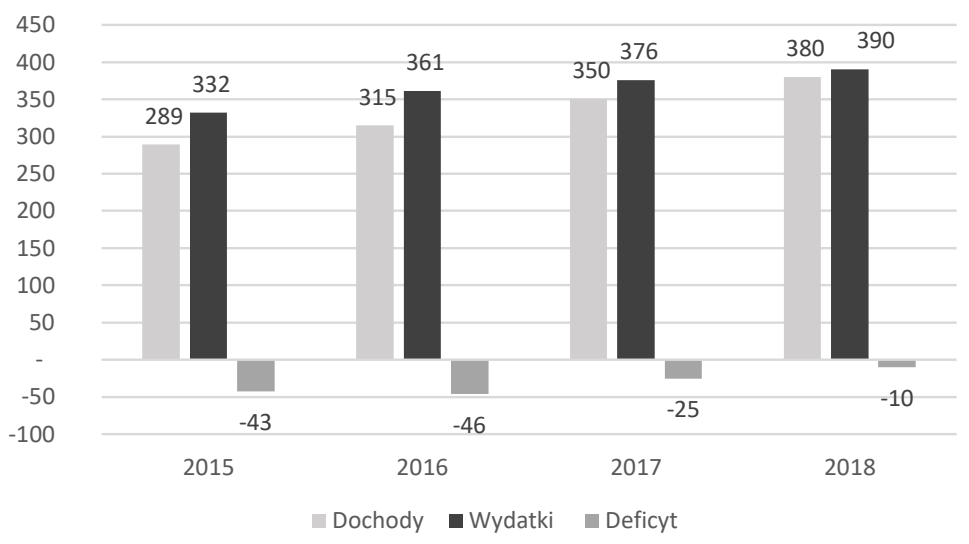

Źródło: opracowanie własne na podstawie danych Ministerstwa Finansów.

Na wykresie 7 pokazano zmiany w dochodach i wydatkach budżetu państwa, a także deficytu budżetowego. Deficyt budżetowy nieznacznie wzrósł w 2016 r., lecz w następnych latach wykazał tendencję malejąca. Można zatem wywnioskować, że wzrostowi wydatków rządowych towarzyszył wzrost dochodów budżetowych, a nie wzrost deficytu, czyli domknięcie II (wzrost dochodów budżetowych jako źródło finansowania programu) okazało się bliższe rzeczywistości.

Na wykresie 7 przedstawiono przychody budżetu państwa. Przychody z podatków wzrastają systematycznie, przy czym po 2016 r. największy jest wzrost przychodów z podatku VAT. Zatem ponownie, post factum można wnioskować, że wybór domknięcia II byłby bardziej uzasadniony. 


\section{Wykres 7}

Dochody budżetu państwa w latach 2014-2018 (mld zł)

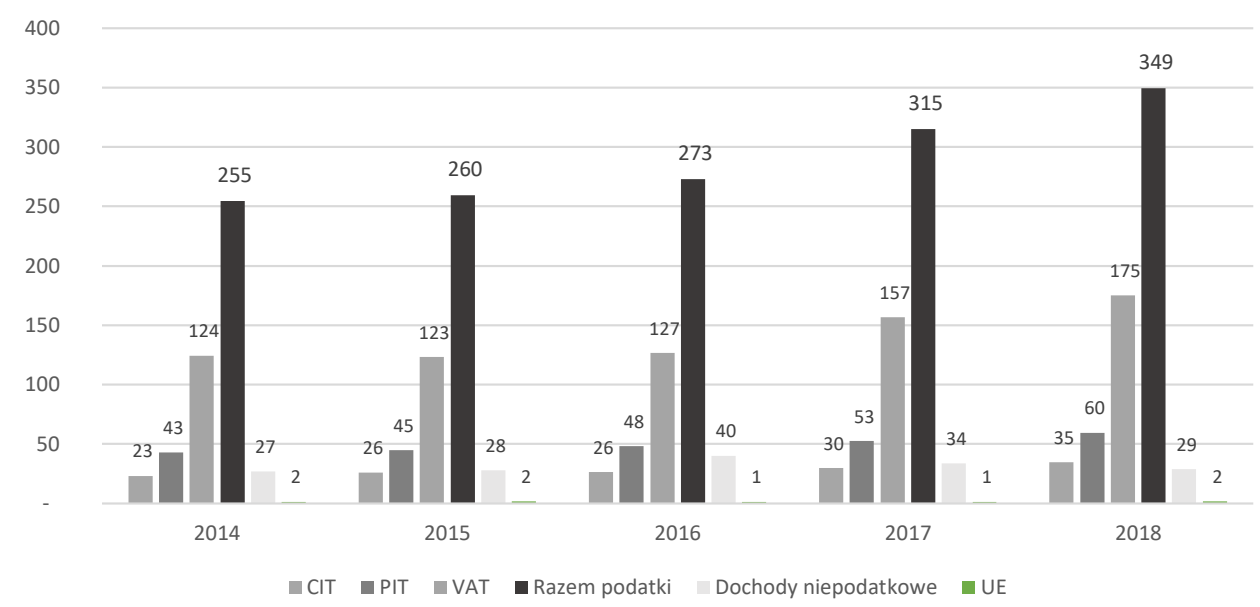

Źródło: opracowanie własne na podstawie danych Ministerstwa Finansów.

Odpowiedź na pytanie, które domknięcie bloku kapitałowego jest bardziej uzasadnione, wiąże się z pytaniem, czy program „Rodzina 500+”, przyczynił się do spadku inwestycji. Z pewnością na to pytanie nie jest łatwo udzielić odpowiedzi, gdyż popyt inwestycyjny zależy od wielu czynników. Na wykresie 8 pokazano składniki popytu krajowego (spożycie i akumulacja brutto) w latach 2015-2018.

\section{Wykres 8}

Popyt krajowy w latach 2015-2018 (mld zł)

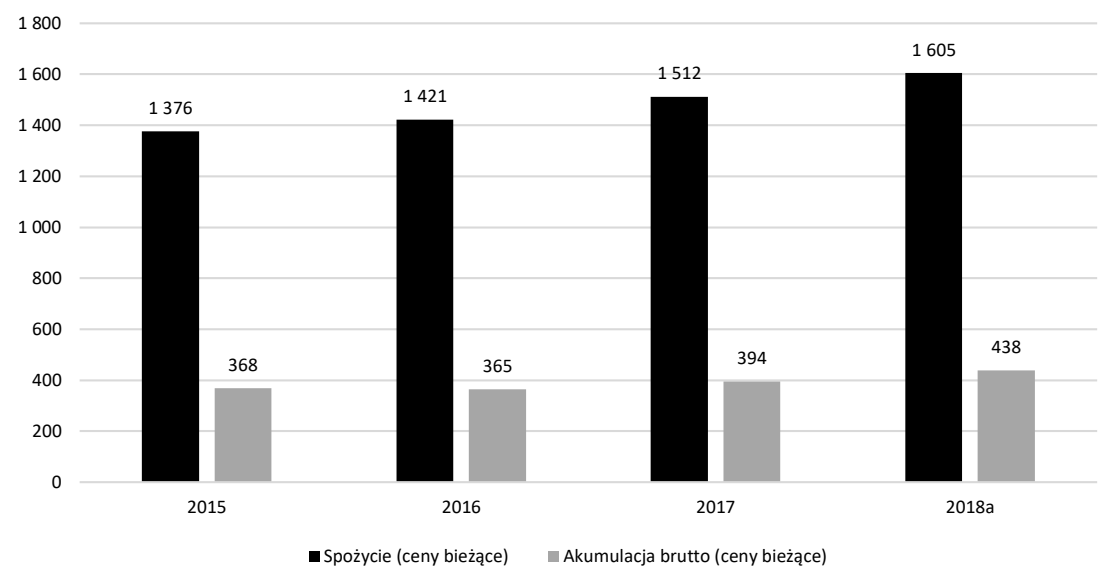

Źródło: opracowanie własne na podstawie danych GUS, Roczne wskaźniki makroekonomiczne, 2018a szacunek wstępny. 
Zarówno konsumpcja (spożycie), jak i akumulacja brutto (inwestycje) wzrosły w badanym okresie. Wzrost konsumpcji wynosi $16,64 \%$, a wzrost inwestycji - 19,03\%. W 2016 r. nastapiło nieznaczne obniżenie popytu inwestycyjnego w porównaniu z rokiem poprzednim, natomiast w kolejnych latach obserwowany jest wzrost. Zatem nie ma podstaw do wnioskowania, że program „Rodzina 500+” przyczynił się do spadku inwestycji. Czy obserwowany wzrost inwestycji byłby większy, gdyby nie było programu „Rodzina 500+” pozostaje pytaniem otwartym. Na tle przedstawionych zmian domknięcie keynesowskie wydaje się bardziej uzasadnione.

\section{WNIOSKI}

Program „Rodzina 500+” jest częścią reformy wsparcia finansowego dla rodzin z dziećmi w Polsce i został wprowadzony w odpowiedzi na problem starzejącego się społeczeństwa. Formuła tego wsparcia wzbudza wiele sporów. Celem przedstawionego badania nie była jednak ocena słuszności tej polityki, lecz jej wpływu na polską gospodarkę za pomoca modelu CGE. Zostało pokazane, że skonstruowany i skalibrowany model z klasy CGE jest odpowiednim narzędziem do badania tego wpływu. Model ten dopuszcza różne scenariusze związane z finansowaniem programu i umożliwia ocenę ich wpływu na wybrane zmienne makroekonomiczne.

Na podstawie przedstawionej analizy można sformułować następujące wnioski o wpływie wprowadzenia programu „Rodzina 500+” na polska gospodarkę: transfery socjalne spowodują wzrost konsumpcji, produkcji krajowej oraz importu. Jest to wniosek zgodny z intuicją ekonomiczną. W ramach domknięcia I, zakładającego wzrost deficytu budżetowego - skutki te są silniejsze w porównaniu z domknięciem II (wzrost dochodów budżetowych). Ten wniosek również nie wzbudza wątpliwości, gdyż jest spójny z podejściem keynesowskim, szeroko stosowanym w wielu krajach, polegajacym na okresowym stymulowaniu gospodarki za pomocą zwiększania długu publicznego.

Kolejny wniosek dotyczy wpływu na inwestycje. Przy domknięciu neoklasycznym wpływ na inwestycje jest negatywny. Jednak wyniki symulacji zależą od zasad domknięcia bloku kapitałowego. Przy neoklasycznym domknięciu bloku kapitałowego zakłada się, że inwestycje dostosowują się do oszczędności, a zatem wzrost konsumpcji wiąże się ze spadkiem oszczędności i stąd ze spadkiem inwestycji. Przy keynesowskim domknięciu bloku kapitałowego inwestycje nie sa uzależnione od poziomu oszczędności, gdyż mogą być finansowane zwiększeniem zadłużenia, więc wzrost wydatków rządowych nie doprowadzi do znacznego spadku inwestycji. Wręcz odwrotnie, zwiększony popyt konsumpcyjny spowoduje wzrost popytu inwestycyjnego. Decyzje inwestycyjne zależą nie tylko od dostępności kapitału, ale także od wielu innych czynników, stąd należy ostrożnie podchodzić do wniosku dotyczącego związku między zwiększonymi wydatkami a rozmiarem inwestycji. 
Podsumowujac, skonstruowany model z klasy CGE może być wykorzystany jako narzędzie do badania wpływu polityki „Rodzina 500+” na polska gospodarkę, a także służyć do prognozowania skutków innych programów socjalnej polityki państwa na główne zmienne makroekonomiczne. Przedstawione badanie wpływu programu „Rodzina 500+” za pomoca modelu CGE stanowi uzupełnienie literatury poświęconej temu programowi.

\section{Rumiana Górska}

Szkoła Gtówna Handlowa w Warszawie

rgorska@sgh.waw.pl

https://orcid.org/0000-0001-9871-3540

Brzeziński M., Najsztub, M. (2017). The impact of "Family 500+" Programme on household incomes, poverty and inequality. Polityka Społeczna 44(1): 16-25.

Chrzanowska M., Landmesser, J.M. (2017). Symulacja efektów ex ante programu "Rodzina 500+", [w:] Taksonomia 28, Klasyfikacja i analiza danych - teoria i zastosowania. Prace Naukowe UE we Wrocławiu 468: 38-46.

Dervis K., de Melo, J., Robinson, S. (1982). General Equilibrium Models for Development Policy, New York: Cambridge University Press.

Devarajan, S., Lewis, J.D., Robinson, S. (1994). Getting the Model Right: The General Equilibrium Approach to Adjustment Policy. Mimeo.

Eltalla, H. (2017). The impact of government expenditure on the Palestinian economy: A CGE Analysis. Journal of Economics and Sustainable Development 8: 2222-2855.

Golinowska, S., Sowa-Kofta, A. (2017). Combating poverty through family cash benefits: on the first results of the Programme "Family 500+" in Poland. Polityka Społeczna 44(1): 7-13.

GUS (2016). Rocznik demograficzny. Warszawa.

GUS (2019). Rocznik demograficzny. Warszawa.

Hagemejer, K. (2017). Is the 500+ child benefit programme overgenerous? Polish social protection expenditure on benefits and services for families with children compared with other Member Countries of the EU and OECD. Polityka Społeczna 44(1): 1-7.

Jung, H.S., Thorbecke, E. (2003). The impact of public education expenditure on human capital, growth, and poverty in Tanzania and Zambia: a general equilibrium approach. Journal of Policy Modeling 25(8): 701-725.

Kłopocka, A.M. (2019). The Family 500+ Programme and functioning of Polish households, [w:] red. I. Kowalska, A. Wasilewska (red.), Stan i perspektywy rozwoju sektora finansów publicznych. Warszawa: SGGW: 73-84.

Landmesser, J., Dudek, H., Chrzanowska, M. (2017): The analysis of the Polish "Family 500+" Programme effects using EUROMOD microsimulation model. Double-blind Peer-reviewed Proceedings of the International Scientific Conference Hradec Economic Days 7(1): 506-512.

Magda, I., Brzeziński, M., Chłoń-Domińczak, A., Kotowska, I., Myck, M., Najsztub, M., Tyrowicz, J., „Rodzina 500 plus” - ocena programu i propozycje zmian. <https://for.org.pl/pl/publikacje/ raporty-for/raport-rodzina-500-plus-ocena-programu-i-propozycje-zmian>.

Magda, I., Kiełczewska, A., Brandt, N. (2018). The "family 500+" child allowance and female labour supply in Poland. OECD Economics Department Working Papers 1481.

McDonald, S., Thierfelder, K. (2007). A Static Applied General Equilibrium Model: Technical Documentation STAGE Version 1, July 2007.

Myck, M. (2016). Estimating labour supply response to the introduction of the Family 500+ Programme. CenEA Working Paper Series, WP01/16.

Odior, E.S.O. (2011). Government spending on education, economic growth and long waves in a CGE micro-simulation analysis: the case of Nigeria. British Journal of Economics, Finance and Management Sciences 1(2): 74-87.

Pierzchalska M. (2017). The Family 500+ Programme: potential impact on demographic processes, the labour market and the pension system. Polityka Społeczna 44(1): 42-50. 
Pyatt, G. (1987). A SAM approach to modelling. Journal of Policy Modeling 10: 327-352.

Pyatt, G. (1991). Fundamentals of social accounting. Economic Systems Research 3: 315-341.

Radzik, P. (2017). The Influence of the Government Family 500+ Programme on the Female Labour Force Participation Rate. VIII International Scientific Conference Analysis of International Relations. Katowice: 57-65.

Robinson, S., Kilkenny, M., Hanson, K. (1990). USDA/ERS Computable General Equilibrium Model of the United States, Economic Research Services, USDA, Staff Report AGES 9049.

Ruzik-Sierdzińska, A. (2018). Krótkookresowe skutki programu Rodzina 500+. Studia z Polityki Publicznej 17(1): 63-76.

Szukalski, P. (2018). Zachowania prokreacyjne w latach 2016-2017. Kontynuacja trendów czy zmiana? Polityka Społeczna 45(10): 1-4.

Wiśniewska, A.,Musiał, M., Świecka, B. (2017). The Program "Family 500 Plus" - Implications for Household Finance in Poland. CBU International Conference Proceedings: 490-494.

\section{ASSESSMENT OF THE IMPACT OF THE 'FAMILY 500+' PROGRAMME ON THE POLISH ECONOMY USING THE CGE MODEL}

\section{$\mathrm{Su} \mathrm{m} \mathrm{m}$ a r y}

The Polish government's policy of financial support for families with children, known as 'Family $500+$ ', has many supporters and opponents. The aim of the article is not to assess whether or not this policy is fair, but to analyse its effects on the economy using the Computable General Equilibrium (CGE) model. For the purposes of this study, a standard single country CGE model was constructed and calibrated using the GAMS software. The following conclusions can be drawn about the impact of the introduction of the 'Family 500+' Programme on the Polish economy. Social transfers will increase consumption, domestic production and imports. With the closure of the model assuming an increase in the budget deficit, these effects are stronger than under the closure assuming an increase in budget revenues. The impact on investments is negative. However, the simulation results depend on the capital block closure. With the neoclassical closure, it is assumed that investment adjusts to saving, so an increase in consumption is associated with a decrease in savings and hence a decrease in investment. With Keynesian closure, investment is not dependent on the level of savings, so an increase in government spending will not lead to a decline in investment.

Keywords: CGE; 'Family 500+'; household consumption; investments 